\title{
We Are the Stories We Tell
}

\author{
CLARE CARDINAL-PETT
}

lowa State University

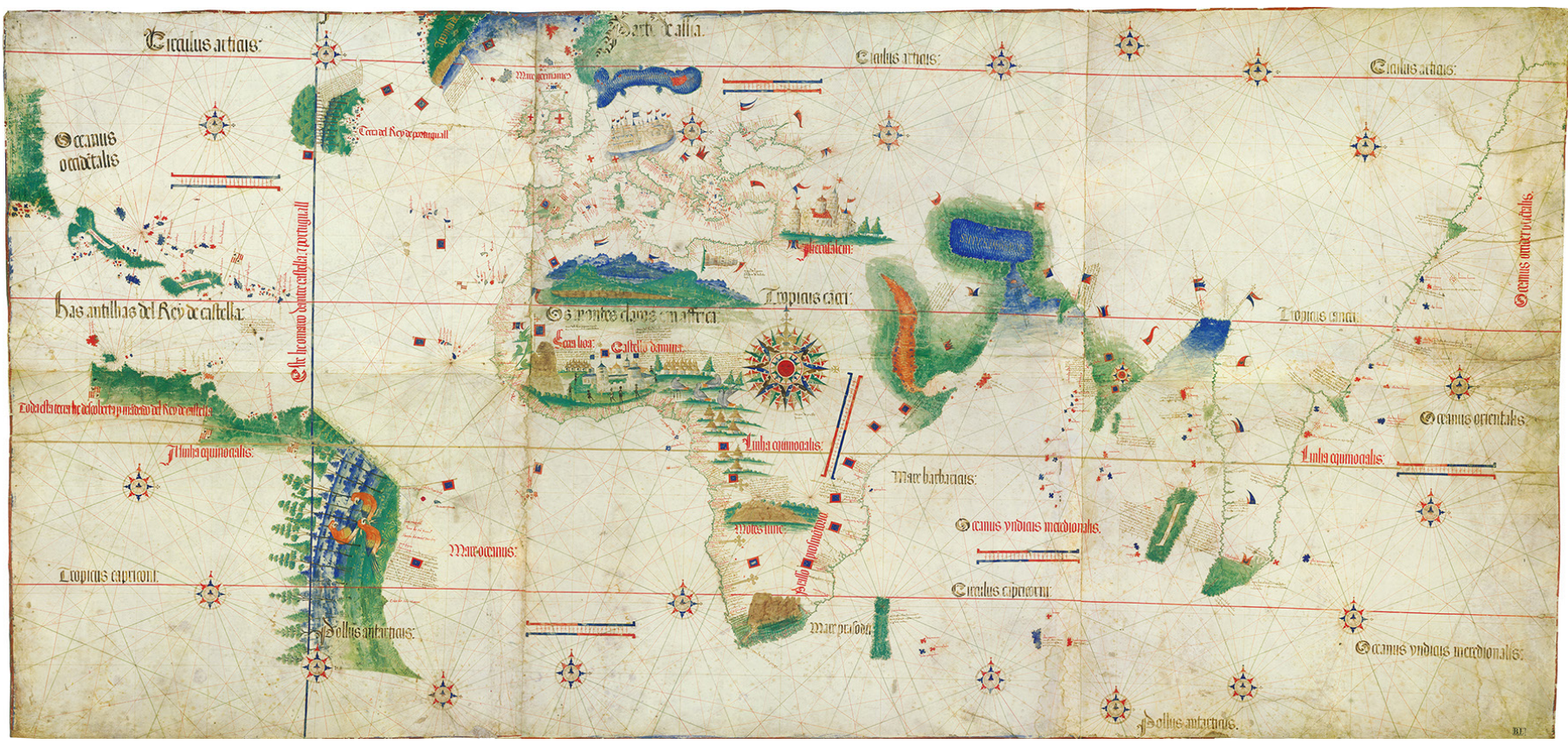

The argument outlined in this paper is simple: understanding what actually happened in the Americas before $1492 \mathrm{CE}$ enlightens our understanding of the present. I hope to contribute to the broad academic discourse about global issues by addressing false assumptions that do not serve to illuminate real places, people, and practices. Perhaps one of the concerns mentioned in the conference call for papers, an "increased contemporary need to develop strategies to cope with future stresses," should be addressed, in part, by rethinking the stories we tell about how we got to the current human condition.

The history of architecture and urbanism seems permanently bound to a Eurocentric narrative. Continuing demand for more inclusive and truly global approaches rarely accomplishes more than the addition of exotic details to this very durable armature. While I recognize the value of more comprehensive global perspectives and support those efforts by scholars and teachers, I also believe that some parts of the world are not rigorously addressed by these worthy attempts. Consequently, the problem of flawed or false fundamental
Figure 1: Cantinoplanisphere 1502 CE The extent of Western European knowledge of world geography at that time.

assumptions remains the dominant pedagogy of architectural history at most institutions worldwide. This paper focuses its attention on a region that has been especially misrepresented, the Americas, and calls for new stories of the evolution of the built environment in this part of the world. It strives to demonstrate how some elements of the Eurocentric structure do not survive scrutiny when challenged with information gleaned from scholarship outside the circle of architecture's traditional sources. Other disciplines such as art history, archaeology, anthropology, geography, and environmental history have other stories to tell.

The paper anchors its position in the exposition of two fundamental and persistent myths. One concerns the first peopling of the Americas, which occurred much earlier than common knowledge allows and spread more people with more diverse life-ways more widely than conventional histories suggest. ${ }^{1}$ The very idea of diverse cultural beginnings-geographically, ecologically, and sociologically-encourages one fundamental revision of perspective. A related assumption that retains a false hold on the historical imagination is 


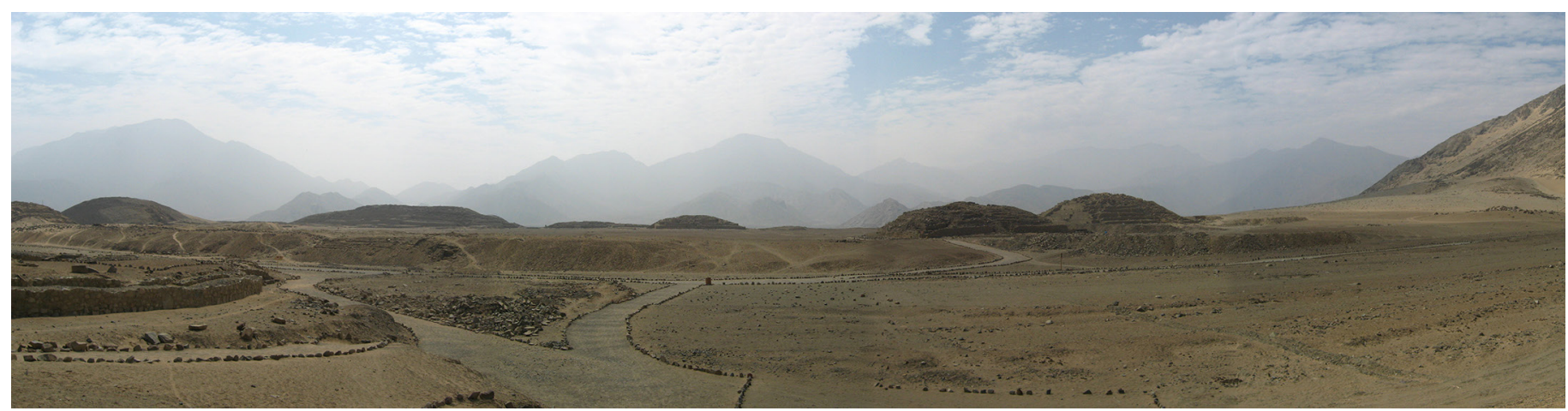

what geographer William Denevan called, "The Pristine Myth," in his revolutionary essay of the same name published in $1992 .{ }^{2}$ The received knowledge that the Americas were "a sparsely populated wilderness - a world of barely perceptible human disturbance" ${ }^{3}$ has allowed historians to ignore thousands of years of environmental transformation. Before Europeans arrived the wilderness "was a humanized landscape almost everywhere." ${ }^{14}$ Although disease quickly decimated indigenous populations and the consequential cultural collapse was profound, the indigenous presence did not vanish. Preexisting urban form, transportation infrastructure, and architecture helped remake the colonizers on the terms of the colonized.

We now know that the land-based theory of migration from Asia to the Americas does not explain the presence of people in South America before the end of the Pleistocene. The consensus among scholars is that some form of rapid coastal dispersal happened at least 14,000 years ago--probably thousands more. There was permanent human settlement along the Pacific Coast as far south as Monte Verde, Chile before any ice-free corridors appeared. There were many more people in many different ecosystems at much earlier dates than previously believed. And people in the Americas started to build permanent communities with complex economies, monumental architecture, and sophisticated cultural histories long before most stories begin. Even the Amazon Basin was densely occupied, much of that forest a product of centuries of human cultivation. ${ }^{5}$

So why is it so important to set the record straight? Because the socalled New World was quite old in 1492 CE and assuming otherwise conveniently erases American history. And assuming otherwise has created obstacles to creating knowledge in many disciplines. The archaeological record has suffered enormous losses because no one thought it worthwhile to dig in uninhabited places.

For example, the Norte Chico just north of Lima, Peru was collection of urban centers with some of the oldest known monumental architecture in the Americas. Parts of it were first excavated only 30 years ago because the sand-covered ruins were mistaken for natural hills. Recent discoveries at sites like Caral, pictured here in Figure 2, have completely revised the timeline of urban history in the Americas and complicated traditional assumptions about early cities and agriculture. People living in the Norte Chico river valleys practiced extensive cooperative agriculture but the main crop was cotton, which they traded for fish, their dietary stable, with people from coastal centers.
Figure 2: A view of the archaeological site of Caral, in the historical Norte Chico region just north of the modern city of Lima, Peru.

There is no evidence of protected urban boundaries in the Norte Chico, no well-guarded storehouses of grain. Widespread cooperation and a robust trade network created its social and political signature. This pattern is unique to the Andean region, where people invented agriculture at the same point in history as other parts of the world and complex urbanisms appeared within a similar time frame as all those other known first cities. ${ }^{6}$

In their 2nd edition of A Global History of Architecture, ${ }^{7}$ Ching, Jarzombek, and Prakash have added content that addresses some of this recent scholarship but the earliest periods of global history covered by the book remain heavily biased towards Eurasian endeavors and, given the authors' lack of attention to the early Americas, most readers will assume that not much happened there before $200 \mathrm{CE}$, when the book first includes more than 3 or 4 pages of examples and text devoted to American history. In its opening preamble "Early Cultures," the book continues to reinforce outdated assumptions about the first migrations--the timeline entries establish the first migrations to the Americas at 13,000 BCE and the first American 'culture' as the Clovis at 10,000-9,000 BCE. While the Monte Verde and Fell's Cave sites in South America are mentioned, some dates are not accurate: people occupied Monte Verde more than 1000 years earlier than the book's timeline entry of 10,500-9,500 BCE.

The only other American timeline entry for this introductory section of the book is the recognition of maize cultivation in 5000 BCE. While maize certainly became an important and widespread staple crop in the Americas much later on the timeline of agricultural developments, it was not the centerpiece of extensive cooperative farming during the earliest periods of urbanization. The subtext of this entry, which ignores the great diversity and sophistication of early food systems and agricultural technologies in the Americas, is important to unpack: most staple food systems in Eurasia were based in cereal grain production, much of it irrigated. In order to sustain concentrated urban populations, the surplus was usually stored and protected from enemies in cities with protected boundaries. The fundamental assumption is that all first cities provided food security for agrarian societies through concentration of resources and, consequently, power to manage the distribution of those resources. The solitary entry "maize cultivation, $5000 \mathrm{BCE}$ " suggests some sort of universal 
benchmark of agricultural technology that the Americas should be measured against in the context of the history of architecture and urbanism. According to the actual history of global agriculture, the table should probably be turned, with Americans far surpassing Eurasians in the art and science of food production well before maize became an important dietary mainstay. Indeed, the earliest use of maize was for fermented beverages, not tortillas--for beer, not bread. ${ }^{8}$

Throughout the Americas, early food systems were robust, diverse, and many people enjoyed what anthropologists call 'affluent' lifestyles. Food, for most, was plentiful. Perhaps this is a partial explanation for why the first American urbanisms are remarkable in their lack of defensive architecture. The iconic image of the first city as a dense compound or walled figure does not pertain to most of the early settlement patterns in the Americas. The open, networked urbanisms-like that of the Norte Chico-seem designed for regional exchange of goods, people, and information. This is also true for the incremental and open sprawl that characterized early Mesomerica, although the cultural patterns and food systems were not the same as that of the Andean region. ${ }^{9}$

In its first chapter (3500 BCE), A Global History of Architecture does not mention any sites in the Americas. This implies that Caral, which is discussed and illustrated in Chapter 2 (2500 BCE), had no history. This particular site in the Norte Chico represents the middle of the region's historical development. There are several sites dated to 3500 BCE or older. ${ }^{10}$ While the book acknowledges that "large tracts of Andean sites have still not been explored and carbon-dated, and their stories remain to be told,"11 the opening of the chapter does not allow for any substantial American contribution to global history should future research question assumptions about the stories of the world's first cities:

"By the beginning of the third millennium BCE, the various riveroriented civilizations were primed for rapid cultural development. There were at the time five principal cultural hubs: China, Egypt, Mesopotamia, Margiana, and the Indus."12

Nevertheless, Caral is carefully illustrated (although it is misplaced on the regional map) and discussed in rich detail:

"If the main plaza, surrounded by mounds high about the valley floor, creates the impression of a vast bounded space reminiscent of a high valley plateau, then the circular sunken plaza, reminiscent of the later kivas of North America, repeats that space on a smaller scale, perhaps corresponding to the lower elements of life. What is not present is what might be called art: there are no sculptures or wall paintings..... Caral's importance lies in its overarching influence. In Eurasia at this time, there were already many different competing world views. But all later Peruvian cultures were developments and elaborations of Caral."13

There are several issues with this description that deserve attention. One is that the analogy between the Andean circular sunken plaza and the North American kiva is a willful, superficial formal analogy that conflates all of "Native America." This type of stereotyping is at the heart of cultural erasure. The people of the Andes and the Colorado Plateau had very different social, political, economic, technological, and environment histories. There is certainly too much distance in time, space, etc. between these two architectural elements to make such an oversimplified observation. The description continues to assume too much: "What is not present is what might be called art..." In fact, many artifacts that "might be called art" have been excavated at Caral and many other sites in the Norte Chico network. ${ }^{14}$ Effigy figures that were the work of an individual artist have been found in the remains of a ceremonial chamber on the platform mound at Aspero, one of Caral primary trade partners, and highly ornamental musical instruments constitute one of Caral's most beautiful revelations.

And finally, the authors have focused too narrowly on Caral as the 'center' of the regional culture. Although some contemporary scholarship and many of the materials prepared to promote tourism in the area have suggested as much, the site's role in the overall Norte Chico networks remains unclear and there is no evidence, to date, to suggest that it was any more or less important that several other ceremonial centers that have not yet received intense archaeological study. ${ }^{15}$ The authors' statement that "Caral's importance lies in its overarching influence" is used to support the claim that the Andean theocracies that followed in Caral's historical wake, all of which tend have a threads of continuity with early cultural production in the Norte Chico, were less complex than "Eurasia's many different competing world views" of the same period. This comparison of one, fairly distinctive regional culture in the much larger, more diverse American hemisphere with all of the variety across the whole of Eurasia is clearly not meaningful.

Having said all this, A Global History of Architecture deserves much praise for including material that is completely missing from almost every other book of architectural history on the market. Furthermore, the information available to our students online (and sometimes in their high school history coursework) is much more likely to misinform them about the early peopling of the Americas and the origins of agriculture and its relationship to urbanization in various parts of the world. American entries on the earliest periods of the global timeline of human environmental transformation are frequently missing or wildly inaccurate. Statements such as the following from the wellregarded Khan Academy's Big History Project available online offer some contrast to the flawed but earnest effort by Ching, Jarzombek, and Prakash:

"As with agriculture, the first human civilizations emerged in the Fertile Crescent. More than 5,000 years ago, large agrarian communities became full-fledged cities like Uruk, Ur and Nippur in Mesopotamia and, later, in the Nile Valley of Egypt at Nekhen and Memphis. Agriculture in the Indus Valley fed the growth of cities at Mohenjo-daro and Harappa. Civilization would come thousands of years later in the Americas. ${ }^{17}$

Many histories of architecture and urbanism start the story of the Americas after 1492 CE. This is the case for Spiros Kostof's $A$ 
History of Architecture: Settings and Rituals ${ }^{18}$ and, except for a bit of Mesoamerican history in Chapters 5 and 7, its update by Richard Ingersoll, World Architecture: a Cross-Cultural History, ${ }^{19}$ follows suit. Fazio's and Moffett's A World History of Architecture ${ }^{20}$ combines the first stories of the Americas with that of Africa in one chapter that appears during the period of European colonial expansion, the tenth chapter of sixteen. The associations of the Americas and Africa with 'the primitive' is implied in much of the Eurocentric tales of the discovery of the 'New World' and it is no accident that the theoretical debates about the nature of 'the primitive hut' intensify in Europe's intellectual circles in response to encounters with the Americas. In his famous essay published in 1587, "Of Cannibals," Montaigne wrote, "One calls 'barbarism' whatever he is not accustomed to." 21

As it turns out, the people Columbus first encountered in the Caribbean were some of the least urbanized people in the Americas at that point. And almost all of them succumbed to new contagious diseases right away. The diseases traveled quickly, in many cases well ahead of the European explorers, killing as much as $90 \%$ of the indigenous people within just a few generations. By the time most European immigrants arrived, the cultivated and managed landscapes of the Americas were re-wilding. This is the primary source of the Pristine Myth. It proved a useful perspective for colonizers with any sort of moral compass and later took on a robust life of its own.

In case you consider yourself immune from its influence, consider these basic demographics and tell me they don't surprise you just a little bit: In 1492 CE, when Columbus first landed, there were at least 54 million people in the Americas. In 1800 CE, after 300 years of European colonization, there were only 24 million people-only 6 million of them Europeans. People of African origin outnumbered Europeans by at least 2 million. Despite the dramatic increase in Africans, indigenous Americans were still were the overall majority even though the population losses had been catastrophic. Although populations varied from region to region, there were approximately 10 million indigenous people in 1800 CE. ${ }^{22}$

Although most histories of architecture and urbanism tend to cover the cultures that European explorers and colonizers encountered after $1492 \mathrm{CE}$, the histories of these cultures are usually not addressed and the idea that some parts of the Americas had been inhabited for centuries by increasingly large numbers of people with complicated political-economies and highly evolved material practices prior to European contact is not common, received knowledge. The indigenous population collapse and the durability of the Pristine Myth have tended to obscure the history of the American landscape in 1492 CE.

In $1492 \mathrm{CE}$, one of the most heavily populated places in the Americas was the Valley of Mexico. It was also one of the largest urban places in the world at the time. The first Europeans were astonished and sent reports of their amazement back to Europe. This map of Tenochtitlan sent to King Charles V by Cortez was copied and published widely. Ironically, it looked a lot like the frontispiece to Thomas More's Utopia, published around the same time. Although Tenochtitlan was certainly no utopia, its urban form and systems-and agricultural

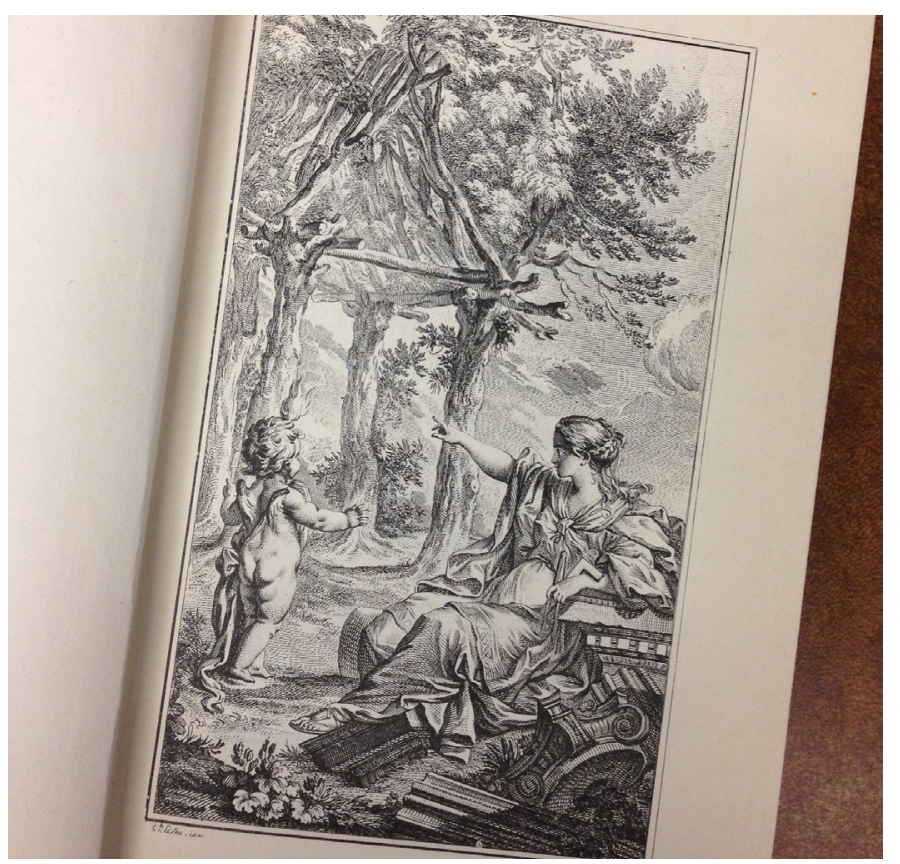

Figure 3: "The Primitive Hut," as illustrated by Charles-Dominique-Joseph Eisen for the 2nd Edition of Abbe Marc-Antoine Laugier's Essai sur l'Architecture published in 1755. The first edition of the Essai was published in 1753.

production--had no rivals in Western Europe. Its long-distance trade networks were equally impressive. The city's enormous, highly regulated central market attracted 25,000 buyers and sellers every day.

The impact of Mesoamerican urban form on subsequent European urban design thinking is now the subject of some interesting scholarship. One important discussion focuses on the history of the grid. Variations on a grid formed the basis of urban patterns on both sides of the Atlantic prior to 1492 . Some places, such as the ancient city of Cholula, Mexico, had very regular grids that the Spanish simply built directly on top of. Another important point of discussion is scale. Mesoamerican urban spaces were really big, much bigger than anything anywhere in Western Europe. After their first encounter with Tenochtitlan and other Mesoamerican cities, the scale of the Spanish American city grids and the central plazas gained ambition. That ambition later returned to Europe. I would argue that Madrid's Plaza Mayor initiated in the late 16th century is one early such instance.

Much of the recent scholarship that explores these and other examples of the entanglement of Mesoamerican urban history and European ideas has been produced by anthropologists (Setha Low) ${ }^{23}$ and art historians (Barbara Mundy). Mundy's most recent book, The Death of Tenochtitlan, the Life of Mexico City published by the University of Texas Press in 2015, is the result of some very careful research that owes little to the conventional architectural history of Mexico's capital city. The publisher's description is a valuable summary of Mundy's radical project:

"The capital of the Aztec empire, Tenochtitlan, was, in its era, one of the largest cities in the world. Built on an island in the middle of a shallow lake, its population numbered perhaps 150,000 , with another 
350,000 people in the urban network clustered around the lake shores. In 1521, at the height of Tenochtitlan's power, which extended over much of Central Mexico, Hernando Cortés and his followers conquered the city. Cortés boasted to King Charles V of Spain that Tenochtitlan was "destroyed and razed to the ground." But was it?

Drawing on period representations of the city in sculptures, texts, and maps, The Death of Aztec Tenochtitlan, the Life of Mexico City builds a convincing case that this global capital remained, through the sixteenth century, very much an Amerindian city. Barbara E. Mundy foregrounds the role the city's indigenous peoples, the Nahua, played in shaping Mexico City through the construction of permanent architecture and engagement in ceremonial actions. She demonstrates that the Aztec ruling elites, who retained power even after the conquest, were instrumental in building and then rebuilding the city. Mundy shows how the Nahua entered into mutually advantageous alliances with the Franciscans to maintain the city's sacred nodes. She also focuses on the practical and symbolic role of the city's extraordinary waterworks - the product of a massive ecological manipulation begun in the fifteenth century-to reveal how the Nahua struggled to maintain control of water resources in early Mexico City."

The Inca Empire, like that of the Mesoamerican Triple Alliance, was a recent development in 1492 and it was also the result of centuries of cultural production in the Andean region. The empire's most famous construction, Machu Picchu was left unfinished and never touched by the Spanish. While the remote ruins are truly beautiful they do not deserve the iconic position they occupy in contemporary global history texts-notably, on the cover of A Global History of Architecture. The Inca Empire built something much more impressive-infrastructure. The Inca transportation infrastructure was built on ancient patterns of trade and social interaction. The Empire expanded and refined these systems to manage corporate agricultural production, storage, and redistribution over a multi-cultural political system that eventually reached 2500 miles north to south, with 15,500 miles of roadways. The Inca Empire's physical infrastructure included new building typologies to facilitate movement of people, animals, and goods-and ideas. Its theocracy involved strategically crafted rituals with well-staffed pathways and shrines to control the hearts and minds of its imperial subjects. The Spanish recognized the brilliance of the system and used it to great advantage. As a result many practices associated with the Inca political-economy still persist in parts of the Andes.

During the American colonial period attempts were made to import foreign patterns, forms, and technologies but much of it failed to take root without expertise and influence from indigenous people. The result was many powerful hybridities. Tenochtitlan/Mexico City's urban form and the Inca/Spanish Empire's political and physical infrastructure are two profound examples. Together, Americans, Europeans, Africans, and Asians in the Americas created a very New World after 1492. Everyone, everywhere changed.

'Modernism' in architecture and urbanism is also one of these hybridities--its history can be traced to the scale of Mesoamerica urban space, among other aspects of the American built environment.

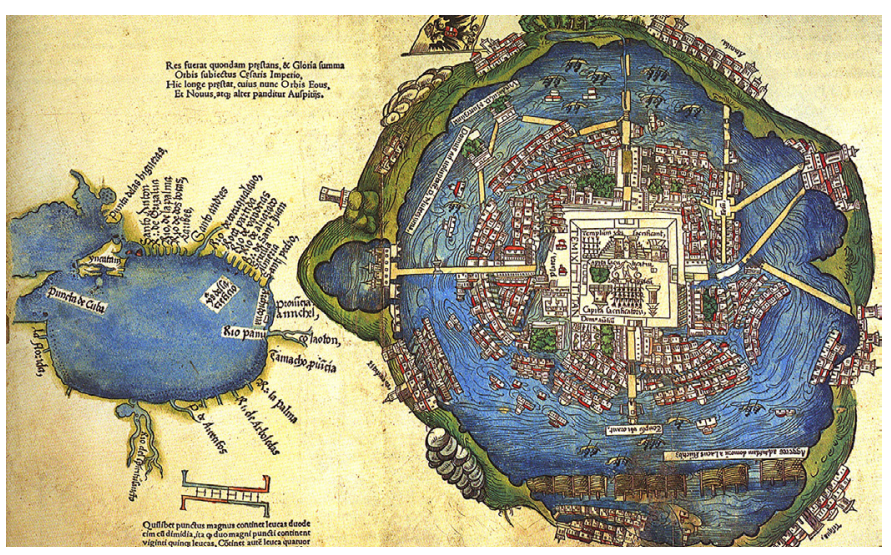

Figure 4: One of Cortez's letters to King Charles V, written from the Americas and first published in 1524, contained a map of Tenochtitlan that was probably executed by Europeans using an Aztec map as a model. ${ }^{23}$ The first woodcut was widely copied and republished, eventually taking on a life of its own. This hand-colored version is one of many later examples.

The origin myth of this particular aspect of the European narrative is begging for a debunking. While a full discussion of the shibboleth is beyond the scope of this paper, an often-neglected thread in the larger story is the short-lived but meaningful attraction of American intellectuals to the indigenous past in the early 20th Century. In the 1920s, during a period of heightened nationalism in the Americas, there was a very widespread intellectual tendency to valorize indigenous cultures and aesthetics. Because there is a diversity of indigenous peoples in the Americas, these movements took on regional character. Frank Lloyd Wright dabbled willfully in this arena but there were more rigorous examples of 'indigenismo' in Mexico and South America. Juan O'Gorman, Mexico's pioneering modernist, was a late adopter of 'indigenismo.' He abandoned architecture altogether in the 1930s and 40s, calling European modernism, a "Frankenstein." In the 1950s, he built himself a house south of Mexico City that he thought was "the most complete and satisfying work that I have done in architecture...It is an example of Organic Architecture, and I think it can be called modern and Mexican."24 O'Gorman's admiration for Frank Lloyd Wright's attempt to cast off the heavy burden of European architectural history by tapping into indigenous traditions is well-known but usually treated as a sort of betrayal:

"I realized long ago that it was unfortunate that Le Corbusier and not Frank Lloyd Wright caught our attention. Wright would have helped us stay closer to our true American tradition...Taliesin [West], the greatest modern project built in this century,... has a recognizable Mexican character. It revives Meso-American tradition. It was Wright..... who understood organic architecture as related to the human being in his geographical and historical content." ${ }^{25}$

And, because it is so delicious, I will finish with this additional mention of how 'indigenismo,' however elitist, intellectualized, and rarely taken seriously, constituted a very serious critique of Western European 'civilization.' Unlike many other nationalistic movements, Brazil's 'modernistas' did not simply reject European cultural 
influences and neo-colonial modernisms, they devoured, digested, and regurgitated them in the manner of Brazil's indigenous Tupi people--who also literally cannibalized Europeans during the early colonial period. While initially a literary movement that argued for the "transformation of the Tabu into a Totem," 26 early modernismo eventually influenced Brazilian art and design more broadly, encouraging the development of tropicality and sensuality in Brazil's most avant-garde architecture after 1930. Burle-Marx, Costa, Niemeyer, and other Brazilian modernistas cannibalized European modern architecture, turning out something "other."

The authors of Primitive: Original Matters in Architecture make the case for the Brazilian cannibalism of Le Corbusier, whose own work took a decidedly less rational and functionalist direction after his engagement with designers in Brazil. I will end with this quote from the book:

"Although he was aware of the Brazilian ideology of cultural cannibalism, Le Corbusier had not foreseen that he would become the 'sacred enemy' of the Brazilian banquet, set '[t]o transform him into a totem.' “27

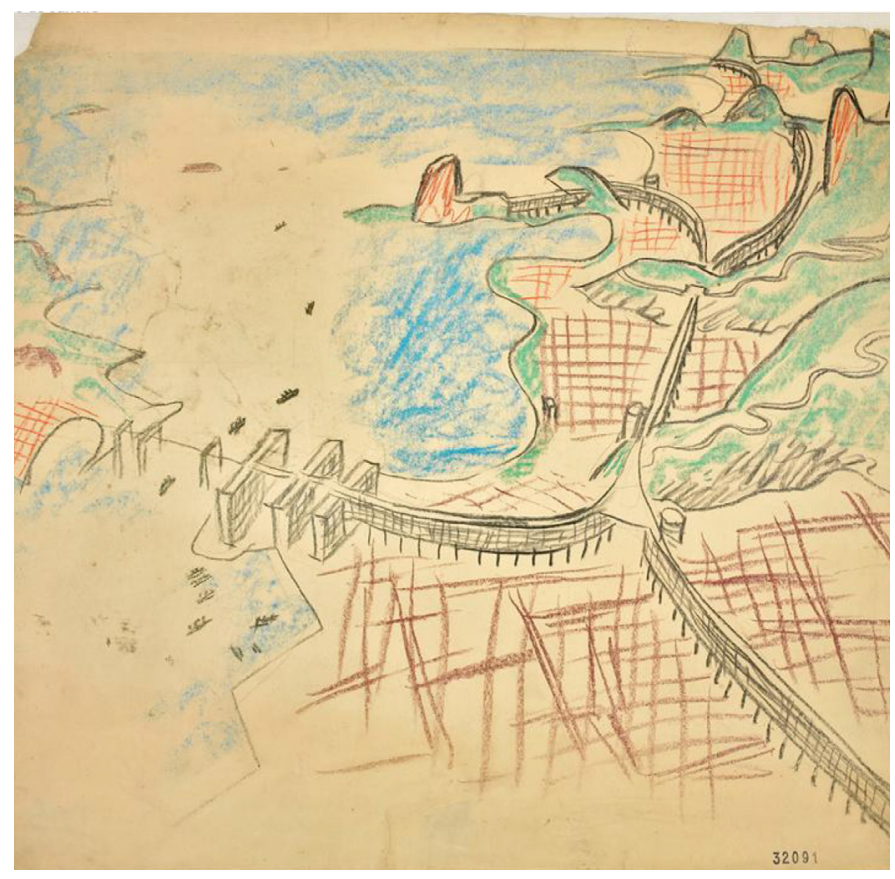

Figure 5: "Un meander" in Rio de Janeiro, Brazil by Le Corbusier, 1930.

\section{ENDNOTES}

1. See, for example, Dillehay, Tom, The Settlement of the Americas: A New Prehistory (New York: Basic Books, 2001).

2. Denevan, William, "The Pristine Myth: the Landscape of the Americas in 1492," in The Annals of the Association of American Geographers, Vol. 83, Issue 3, 1992.

3. Denevan, "The Pristine Myth..."

4. Denevan, "The Pristine Myth..."

5. For a full discussion of human migration into the Americas and a full list of sources for the information that supports this argument, see "Origins," the prologue of my recent book, A History of Architecture and Urbanism in the Americas (London and New York: Routledge, 2016).

6. A good, brief summary of the findings in the Norte Chico to date by Jonathan Haas and Winifred Creamer, project directors at the Field Museum in Chicago, IL USA can be found at the Proyecto Arqueológico Norte Chico (PANC) website: https://www. fieldmuseum.org/file/484421

7. Ching, Jarzombek, and Prakash, A Global History of Architecture, 2nd revised edition, (Hoboken, New Jersey: John Wiley, 2011).

8. Cardinal-Pett, A History...., page 82.

9. For a complete discussion, with references see Chapter 1 "Settings and Settlements," in Cardinal-Pett, A History..."

10. For a complete discussion, with references see Chapter 1 "Settings and Settlements" in Cardinal-Pett, A History..."

11. Ching, et. al, A Global History..., page 25.

12. Ching, et. al, A Global History..., page 25.

13. Ching, et. al, A Global History..., pages 53-54.

14. For a complete discussion, with references see Chapter 1 "Settings and Settlements," in Cardinal-Pett, A History..."

15. For a complete discussion, with references see Chapter 1 "Settings and Settlements," in Cardinal-Pett, A History..."

16. Ching, et. al, A Global History..., page 54

17. https://www.khanacademy.org/partner-content/big-history-project/ agriculture-civilization/first-cities-states/a/gallery-civilization

18. Kostof, Spiros, A History of Architecture: Settings and Rituals, 2nd edition (Oxford: Oxford University Press, 1995).

19. Ingersoll, Richard and Kostof, Spiros, World Architecture: a Cross-Cultural History, (Oxford University Press, 2012).

20. Fazio, Michael, Moffett, Marian, and Wodehouse, Lawrence, A World History of Architecture, 2nd revised edition (New York: McGraw-Hill Education, 2008). History, (Oxford University Press, 2012).

21. For a complete discussion, with references see Chapter 6, "Architecture and Identity," in Cardinal-Pett, A History..."

22. See Low, Setha, "Indigenous Architecture and the Spanish American Plaza in Mesoamerica and the Caribbean," American Anthropologist, New Series, Vol. 97, no. 4 (December 1995) pp. 748-762.

23. For the full story of this map, see Mundy, Barbara, "Mapping the Aztec Capital," Imago Mundi, Vol. 50 (1998) pp. 11-33.

24. Edward Rudolf Burian, Modernity and the Architecture of Mexico, pg. 143.

25. Edward Rudolf Burian, Modernity and the Architecture of Mexico, pg. 143.

26. Oswalde de Andrade, "Manifesto Antropófago," in the first edition of Revisto Antropofagia, Sao Paulo, Brazil in May 1928.

27. Jo Odgers, Flora Samuel, and Adam Sharr, Primitive: Original Matters in Architecture (New York: Routledge, 2006) pg. 119. 